Article

\title{
One New Phenolic Compound from Castanea mollissima Shells and its Suppression of HepatomaCell Proliferation and Inflammation by Inhibiting NF- $\mathrm{B}$ Pathway
}

\author{
Wu Fei ${ }^{1, \dagger}$, Yao Xuan ${ }^{2,+}{ }^{+}$, Xu Jian ${ }^{3, \dagger}$, Wu Yue ${ }^{3}$, Yang Yuejun ${ }^{3}$, Jin Yu ${ }^{4}$, Xie Huifang ${ }^{5}$, \\ Liu Yuancai ${ }^{3, *}$, Yang Yifu ${ }^{2, *}$ and Zheng Xiangwei ${ }^{1, *}$ \\ 1 Shanghai University of Traditional Chinese Medicine Engineering Research Center of Modern Preparation \\ Technology of TCM, Ministry of Education, Shanghai, 200000,China; wufei_shutcm@126.com \\ 2 Shanghai University of Traditional Chinese Medicine, Shanghai, 200000, China; shane.yao@163.com \\ 3 Jing Brand Research Institute, Jing Brand Co., Ltd., Daye, 435100, China; xujian@jingpai.com (X.J.); \\ proyue1122@gmail.com(W.Y.); yyj@jingpai.com (Y.Y.) \\ 4 Engineering Research Center of Pharmaceutical Process Chemistry, Ministry of Education, \\ School of Pharmacy, East China University of Science and Technology, Shanghai, 200000, China; \\ Jiny@ecust.edu.cn \\ 5 Biotechnology Research \& Innovation Department, Shanghai Huangdian Co., Ltd., Shanghai, 200000, China; \\ hf_xie@sina.com \\ * Correspondence: lyc@jingpai.com (L.Y.); yangyifu@mail.shcnc.ac.cn (Y.Y.); zhengxwsh@hotmail.com (Z.X.); \\ Tel./Fax: +86-714-8768056/+86-714-8770541 (L.Y.); +86-21-51323139/+86-21-51323094 (Y.Y.); \\ $+86-21-51323139 /+86-21-51323094$ (Z.X.) \\ + These authors contributed equally to this work.
}

Received: 15 January 2019; Accepted: 18 January 2019; Published: 22 January 2019

\begin{abstract}
Shells of Castanea mollissima (CMS), an agricultural remain and often considered waste from chestnut processing industry, have been proven a resource for traditional Chinese medicine. One new phenol, named castanolB(1), andsix known phenolic compounds (2-7) were isolated froma water-soluble extract of CMS. Their chemical structures were determined using preparative HPLC and various spectral analyses, and then were compared to literatures, which indicated the first identification of the seven compounds from C. mollissima. The physicochemical property of compound (2) was also reported for the first time. After antiproliferative screening of compounds (1-7) on LPS-induced SMMC-7721 and HepG2 hepatoma cells, castanolB (1) showed the best suppression. CastanolB(1) also significantly induced cell apoptosis. Furthermore, castanolB (1) decreasedsecretion of TNF- $\alpha$ and IL-6. Mechanistically, TLR4-NF- $\mathrm{kB}$ pathway was inhibited bycastanolB (1) with downregulation of TLR4, IKK $\beta$, and NF-KB p65. This study presents a new phenol and shows its profiles of anticancer and anti-inflammation via inhibiting the TLR4-NF- $\kappa B$ pathway.
\end{abstract}

Keywords: Castanea mollissima shells; phenols; anti-inflammatory activities; anticancer activities; hepatoma cells; TLR4-NF-kB pathway

\section{Introduction}

Chinese chestnut (Castanea mollissima) is one of the highest-yielding dried fruits in the world [1]. According to 2016 statistical data from FAOSTAT (Food and Agriculture Organization of the United Nations), the world chestnut production reaches 2.3 million tons, of which China accounts for about 1.9 million tons [2]. As the exocarp, the shells of C.mollissima (CMS) generate a huge amount of waste, whichhas little further use. CMS can be used as fuel or processed into dyes and herbs; 
however, the utilization is extremely low, resulting in resource waste and environmental pollution, it is therefore necessary to dig out the value of CMS. In traditional Chinese medicine (TCM), CMS is a kind of herbs for treating various diseases, such as regurgitation, epistaxis, hemafecia, pertussis, and so on [1]. In this study, we hope to identify the chemical compositionand the bioactivities of CMS extract.

Several researchers have explored the biological activities of CMS extract and the chemical composition of its fat-soluble parts. You et al. [3] assessed the antimicrobial activity and DPPH scavenge capacity of CMS extract. Zhang et al. [4] found that CMS extract triggered necrosis and arrested the cell cycle of HepG2 cells. In addition to the bioactivity researches on CMS extract, 16 compoundswere isolated and identified the structures from the fat-soluble extract of CMS [1]. However, it has been rarely reported the chemical composition of water-soluble extract of CMS, as well as the active ingredients structures, because CMS contains a lot of water-soluble tannins and melanin impurities which cause difficulties on compoundisolation and purification. In this study, we firstly aimed to isolate and purify the water-soluble chemical components of CMS, and to identify the isolates structures by preparative HPLC. Then, all isolates were focused on the anti-hepatoma activity screening because Zhang et al. [4] confirmed the proapoptotic effect of CMS on hepatoma cells. Furthermore, a new compound, castanolB (1), was evaluated for its combined mechanism of anti-inflammation and anticancer.

\section{Results}

\subsection{Chemistry}

The methanol extract of CMS was subjected to preparative HPLC to yield one new compound castanolB (1), together with six known compounds. Compound 2 was identified as 7,8-dihydroxy-2H-chromen-3-one (2) (CAS: 56022-24-3), which physicochemical profiles was firstly reported. Then the structures of the other five compounds, after their physicochemical data were compared to reported literatures, were elucidatedas 7,8,9-trihydroxy-chromen-2-one(3) [5], 3-(3,4-dihydroxyphenyl)-4-hydroxycyclohexanone (4) [6], brevifolin carboxylic acid (5) [7], (3R,4R)-3-(3,4-dihydroxyphenyl)-4-hydroxycyclohexanone(6) [8], and (4R)-5-(1-(3,4-dihydrophenyl)-3-oxobutyl)-dihydrofuran-2(3H)-one(7) [6]. Of them, compounds (2)-(7) were identified the existence in C. mollissima for the first time (Figure 1).

Compound 1, a pale yellow powder, was analyzed the molecular formula by high resolution-electrospray ionization-mass spectrometry (HR-ESI-MS) and was deduced to be $\mathrm{C}_{13} \mathrm{H}_{10} \mathrm{O}_{5}$ at $\mathrm{m} / \mathrm{z} 245.0462[\mathrm{M}-\mathrm{H}]^{-}$. The benzene rings, phenyl and carboxyl groups were identified by the possible characteristic absorptions showed by its UV spectrum in $\mathrm{MeOH}$ at $\lambda \max 210,247$, and $255 \mathrm{~nm}$. Compound 1 also contained $\mathrm{OH}$ groups $\left(3289 \mathrm{~cm}^{-1}\right), \mathrm{C}=\mathrm{O}$ groups $\left(1762 \mathrm{~cm}^{-1}\right)$, and aromatic rings $(1615$, 1585 , and $1486 \mathrm{~cm}^{-1}$ ) using the IR spectrum. According to ${ }^{1} \mathrm{H}-\mathrm{NMR}$ spectrum, compound 1 displayed the ABX-coupled system $\mathrm{H}$-atoms at $\delta_{\mathrm{H}} 6.83(d, 1 \mathrm{H}, J=12.0 \mathrm{~Hz}), \delta_{\mathrm{H}} 6.95(d d, 1 \mathrm{H}, J=12.0,6.0 \mathrm{~Hz})$, and $\delta_{\mathrm{H}}$ $7.05(d, 1 \mathrm{H}, J=6.0 \mathrm{~Hz})$, as well as three single aromatic $\mathrm{H}$-atoms at $87.14,7.33$, and 7.66. Analyses of ${ }^{13} \mathrm{C}$ NMR and DEPT spectra data (Table 1 ) indicated thirteen carbons, including one carboxyl quaternary carbon at $\delta 169.9$ and twelve aromatic carbons. These observations suggested that $\mathbf{1}$ had a biphenyl skeleton and a carboxy side chain. Additionally, it showed cross peaks between $\delta_{\mathrm{C}} 169.9(\mathrm{C}-7) / \delta_{\mathrm{H}}$ $7.66(\mathrm{H}-2), \delta_{\mathrm{H}} 7.33(\mathrm{H}-4)$, and the $\mathrm{C}-1^{\prime}$ at the $\mathrm{C}-1$ between $\delta_{\mathrm{C}} 132.2(\mathrm{C}-1) / \delta_{\mathrm{H}} 7.05\left(\mathrm{H}-2^{\prime}\right)$ in the HMBC spectrum of 1 (Figure 2), and verified a carboxyl group linking at the C-3. The structure of $\mathbf{1}$, as stated in these spectral data, was elucidated as 5,3', $4^{\prime}$-trihydroxy-3-carboxyl-biphenyl, which parent nucleus was biphenyl skeleton and was same to dimethyl dicarboxylate biphenyl (DDB) (Figure 3). 
<smiles>O=C(O)c1cc(O)cc(-c2ccc(O)c(O)c2)c1</smiles><smiles>O=C1COc2cc(O)c(O)cc2C1</smiles><smiles>O=c1ccc2cc(O)c(O)c(O)c2o1</smiles><smiles>O=C1CCC(O)[C@H](c2ccc(O)c(O)c2)C1</smiles><smiles>CC1CC(=O)c2oc(=O)c3cc(O)c(O)c(O)c3c21</smiles><smiles>O=C1CCC(Cc2ccc(O)c(O)c2)O1</smiles><smiles>CC(=O)CCC1OC(=O)C[C@H]1c1ccc(O)c(O)c1</smiles>

Figure 1. Structures of compounds (1)-(7) from water-soluble extracts of Castanea mollissima shells.<smiles>O=C(O)C12CCCCC1c1cccc(c1O)CCN2</smiles>

1

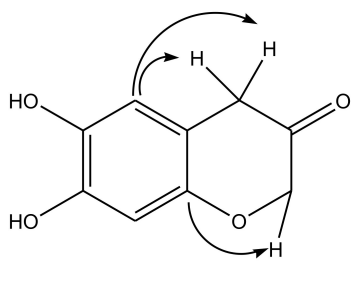

2

$$
\mathrm{C} \overbrace{\mathrm{H} \text { HMBC }}
$$

Figure 2. Key HMBC correlations of compounds (1)-(2) (C-H).

Table 1. ${ }^{13} \mathrm{C}$ NMR data of compounds1-2 (125 MHz; in DMSO) ( $\delta$ ppm).

\begin{tabular}{ccc}
\hline No. & $\mathbf{1}$ & $\mathbf{2}$ \\
\hline 1 & 132.2 & \\
2 & 118.6 & 73.6 \\
3 & 116.9 & 206.7 \\
4 & 113.9 & 34.8 \\
5 & 157.5 & 125.8 \\
6 & 116.9 & 111.2 \\
7 & 169.9 & 154.6 \\
8 & & 148.0 \\
9 & & 108.2 \\
10 & & 148. \\
$1^{\prime}$ & 145.1 & \\
$2^{\prime}$ & 113.5 & \\
$3^{\prime}$ & 145.2 & \\
$4^{\prime}$ & 142.6 & \\
$5^{\prime}$ & 115.3 & \\
$6^{\prime}$ & 118.0 & \\
\hline
\end{tabular}




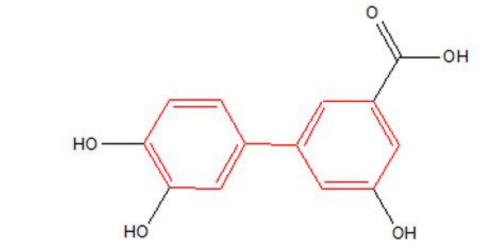

$5,3 ', 4$ ' - trihydroxy -3- carboxyl - biphenyl.

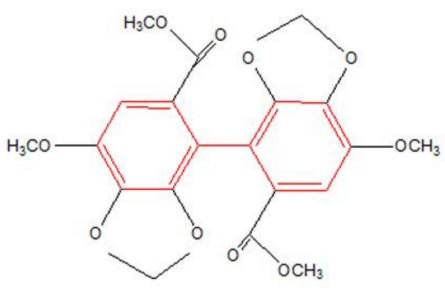

dimethyl dicarboxylate biphenyl

Figure 3. The biphenyl skeleton in compound (1) and dimethyl dicarboxylate biphenyl (DDB).

Compound 2 was also a pale yellow powder. HR-ESI-MS data at m/z 179.0467 [M-H] ${ }^{-}$showed its molecular formula as $\mathrm{C}_{9} \mathrm{H}_{8} \mathrm{O}_{4}$. The benzene rings and ketone groups were identified by the possible characteristic absorptions showed by its UV spectrum in $\mathrm{MeOH}$ at $\lambda \max 227$ and $255 \mathrm{~nm}$, respectively. Compound 2 also contained $\mathrm{OH}$ groups $\left(3320 \mathrm{~cm}^{-1}\right), \mathrm{C}=\mathrm{O}$ groups $\left(1754 \mathrm{~cm}^{-1}\right), \mathrm{C}-\mathrm{O}$ groups $\left(1170 \mathrm{~cm}^{-1}\right)$, and aromatic rings $\left(1618,1580\right.$, and $\left.1480 \mathrm{~cm}^{-1}\right)$ using the IR spectrum. The HMQCand ${ }^{1} \mathrm{H}-\mathrm{NMR}$ spectrum of 2 showed the presence of two single aromatic $\mathrm{H}$-atoms at $\delta 7.07,6.84$, an oxymethyleneH-atoms at 4.45 (s), and a methyleneH-atoms at $\delta 2.75,3.42$. By analyses of the ${ }^{13} \mathrm{C}$ NMR and DEPT spectra data (Table 1), it indicated nine carbons, including one ketone quaternary carbon at $\delta 206.7$, an oxygen linked quaternary carbon at $\delta 73.6$, a methylene carbon at $\delta 73.6$, and six aromatic carbons. These observations suggested that 2 had a phenylpropanoid skeleton. Additionally, the oxymethylene group was linked to the benzene ring through oxygen, which was analyzed by the cross peaks between $\delta_{\mathrm{C}} 148.1(\mathrm{C}-10) / \delta_{\mathrm{H}} 4.40(\mathrm{H}-2)$, while a methylene group was directly linked to the benzene ring, which was investigated by the cross peaks between $\delta_{\mathrm{C}} 111.2(\mathrm{C}-6) / \delta_{\mathrm{H}} 2.75,3.42(\mathrm{H}-4)$ according to the HMBC spectrum of 2 (Figure 2). The structure of 2, as stated in these spectral datas, was elucidated as 7, 8-dihydroxy-2H-chromen-3-one.

\subsection{Antiproliferative Effect of These Compounds}

In vitro cell models were established using lipopolysaccharide (LPS)-induced SMMC-7721 cells (human hepatoma cell line) and LPS-induced HepG2 cells (human hepatoma cell line). Briefly, the malignant cancer hallmarks, such as proliferation, can be accelerated by inflammation, which is caused by LPS. And the deteriorated process can be partly prevented by certain compounds. In this study, the concentrations of all compounds in preventing LPS-induced hepatoma cells proliferation were $200 \mu \mathrm{M}, 100 \mu \mathrm{M}$,and $50 \mu \mathrm{M}$. Then, cell proliferation was detected using a MTT assay with standard protocol. In Figure 4A,B, LPS significantly induced cell proliferation compared with those of vehicle; compared to the LPS group, castanol B (1) showed greater than $50 \%$ inhibition at both dosages of $200 \mu \mathrm{M}$ and $100 \mu \mathrm{M}$ on two cell lines. Compounds (4), (6), and (7) were found to have moderate inhibition at $200 \mu \mathrm{M}$. Compounds (2), (3), and (5) showed faint activity compared to (1), (4), (6), and (7).

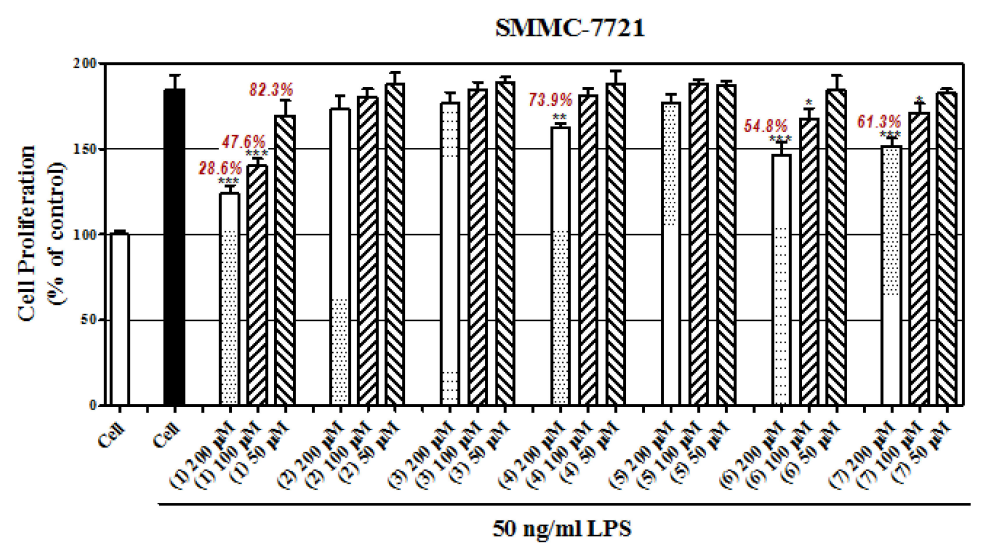

Figure 4. Cont. 


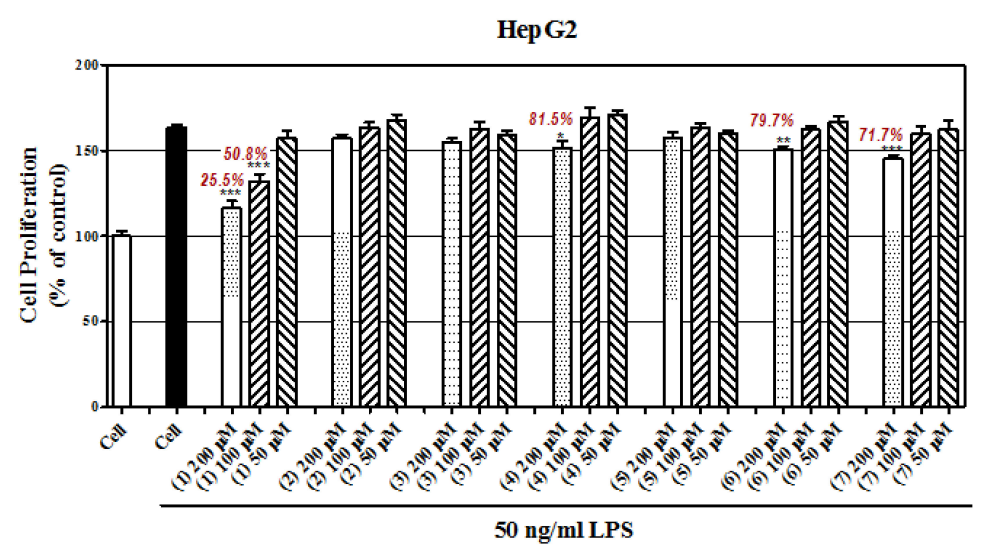

Figure 4. Effect of compounds on inhibition of lipopolysaccharide (LPS)-induced hepatomacell proliferation of SMMC-7721 cells (A) and HepG2 cells (B). ( ${ }^{*}$ denotes $p<0.05$; ** denotes $p<0.01$; *** denotes $p<0.001$, vs. LPS-induced hepatoma cells).

\subsection{Castanol B(1)-Induced Cellular Apoptosis}

In Figure 5, we measured the proapoptotic effects of castanol B (1) using Annexin V/propidium iodide (PI) assay after $48 \mathrm{~h}$ treatment of two hepatoma cell lines with castanol B (1). Low concentrations of LPS markedly decreased the apoptosis rate of both SMMC-7721 and HepG2 cells compared to control cells; $200 \mu \mathrm{M}$ and $100 \mu \mathrm{M}$ of castanol B (1) significantly promoted apoptosis compared to LPS-induced cells. Additionally, castanol B (1) significantlyincreased the apoptosis rate of both cells in the absence of LPS. These results indicated that the antiproliferative effect of castanol B(1) might be explained by its proapoptotic characteristic. However, the further mechanism against proliferation should be studied.
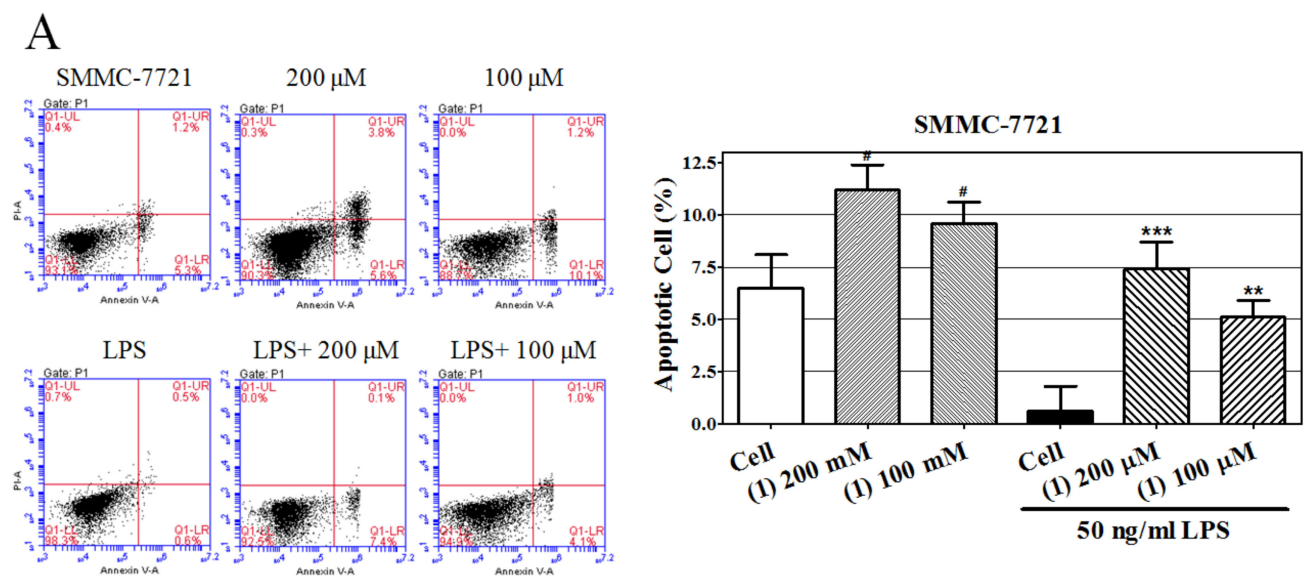

Figure 5. Cont. 
B
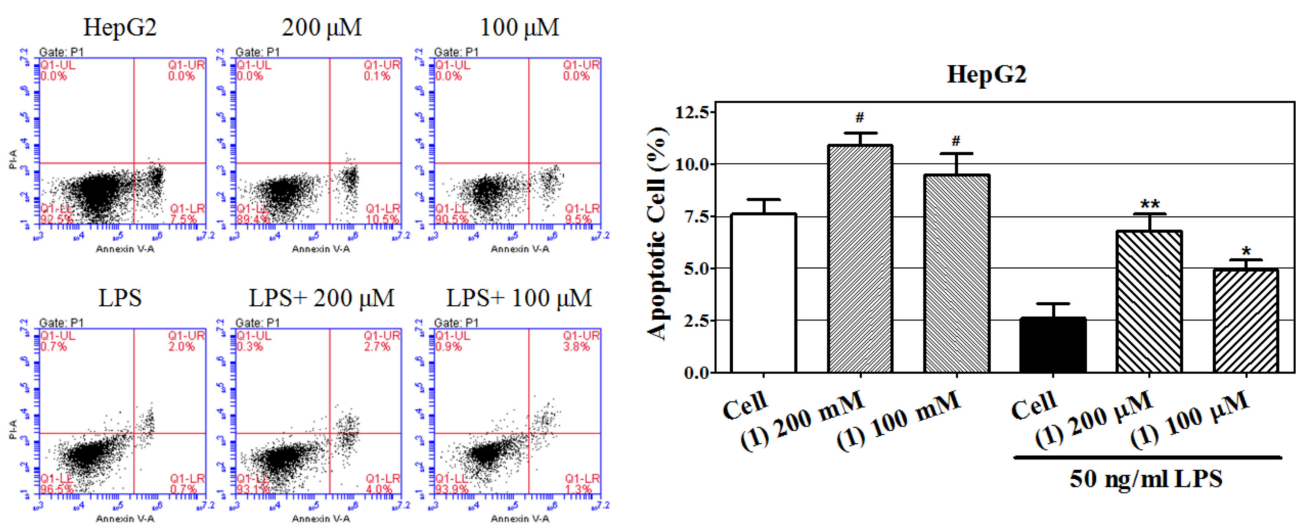

Figure 5. Effect of castanol B (1) on apoptosis of lipopolysaccharide(LPS)-induced hepatomaSMMC-7721 cells of SMMC-7721 cells (A) and HepG2 cells (B). (\# denotes $p<0.05$ vs. vehicle-treated hepatoma cells.

${ }^{*}$ denotes $p<0.05$; ${ }^{* *}$ denotes $p<0.01$; ${ }^{* * *}$ denotes $p<0.001$, vs. LPS-induced hepatoma cells).

\subsection{Effect of Castanol B (1) on LPS-Induced TNF- $\alpha$ and IL-6 Secretion in Hepatoma Cells}

In order to verify the anti-inflammatory effect ofcastanol B (1)in SMMC-7721 and HepG2 cells, we measured the concentration of two key pro-inflammatory cytokines (TNF- $\alpha$ and IL-6) in the supernatant using ELISA. As shown in Figure 6, TNF- $\alpha$ and IL-6 were dramatically increased by LPS in SMMC-7721 and HepG2 cells, while their concentrations were markably decreased by $200 \mu \mathrm{M}$ and $100 \mu \mathrm{M}$ of castanol B (1) in a dose-dependent manner.

A

$\mathrm{B}$
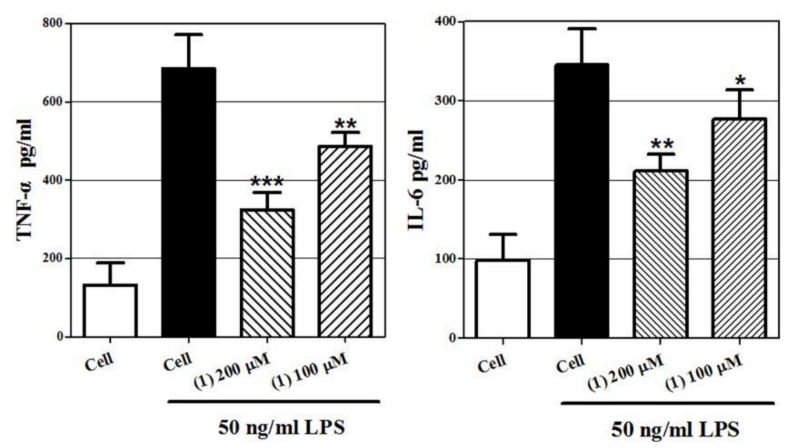

C

D
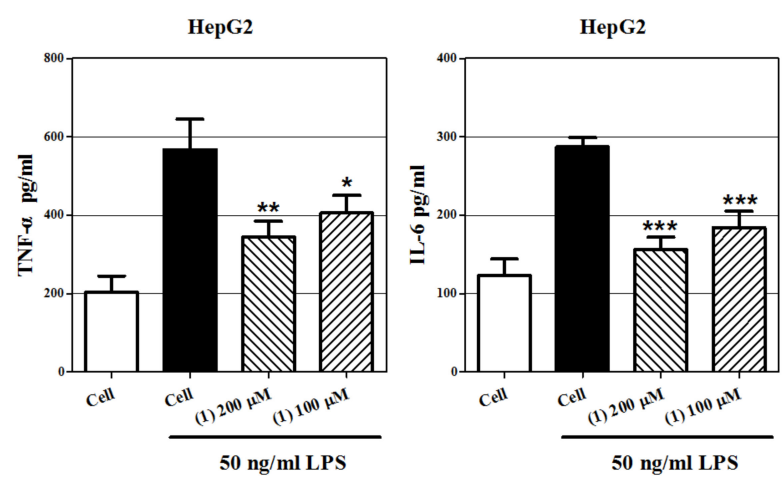

Figure 6. Effect of castanol B (1) on cytokines secretionon lipopolysaccharide(LPS)-induced hepatoma cells. TNF- $\alpha$ (A) and IL-6 (B) expression in SMMC-7721 cells was inhibited by castanol B (1). TNF- $\alpha\left(\right.$ C) and IL-6 (D) expression in HepG2 cells was inhibited by castanol B (1). ( ${ }^{*}$ denotes $p<0.05$;

${ }^{* *}$ denotes $p<0.01$; ${ }^{* * *}$ denotes $p<0.001$, vs. LPS-induced hepatoma cells). 


\subsection{Effect Castanol B (1) on the TLR4-NF-kBSignal Pathway}

In Figure 7, the expression levels of TLR4 and its downregulated proteins in the NF-kB pathway were detected by Western blot analysis. As compared to the control cells, LPS induced significant augmentation of TLR4, IKK $\beta$, and NF- $\kappa B$ p65 indicating that LPS-induced TLR4 could activate the NF- $k B$ signal pathway. However, the $200 \mu \mathrm{M}$ castanol B (1) treatment significantly prevented the activation of NF-KB p65, IKK $\beta$, and TLR4.

\section{A}

\section{SMMC-7721}
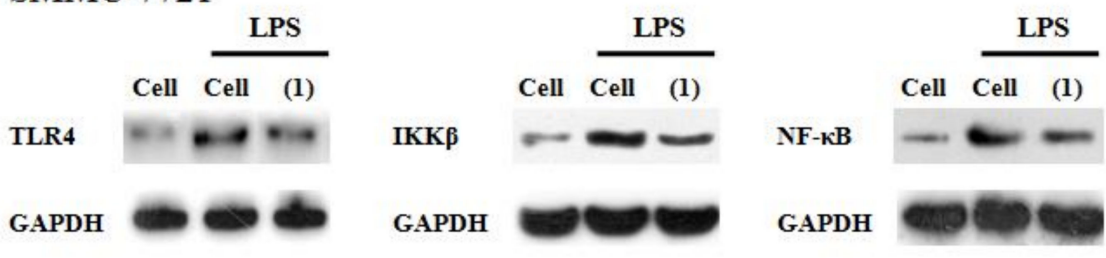

B
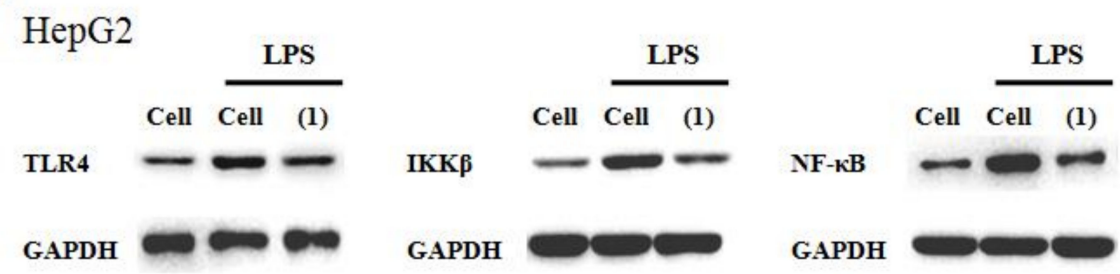

Figure 7. Effect of $200 \mu \mathrm{M}$ castanol B (1) on theexpression of proteins TLR4, IKK $\beta$, and NF- $\mathrm{KB}$ p65 in lipopolysaccharide(LPS)-induced SMMC-7721 cells (A) and HepG2 cells (B).

\section{Discussion}

In this present study, seven compounds were purified and identified from the water-soluble extract of CMS. Castanol B (1) was a new structure compound and 7,8-dihydroxy-2H-chromen-3-one (2) was firstly reported in the physicochemical data. The parent nucleus of castanol B (1) is a biphenyl skeleton and the same as DDB, a hepatoprotective agent commonly used in treating viral hepatitis in many Asian countries and treating hepatitis B in China $[9,10]$. It has been also verified the inhibitory effect of DDB on invasion of human hepatoma cell with high metastasis potential [11], and the ability to reverse multidrug resistant cancer cells, such as breast carcinoma cellsin vitro [10]. In addition, castanol B (1), as one of the polyphenols, perhaps exhibits the anti-inflammatory properties of polyphenol, such as catechin and epigallocatechin. It has been considered that chronic inflammation is one of the most essential factors leading to tumorigenesis and metastatic progression of hepatocellular carcinoma [12,13]; DDB presents the properties of both anticancer and anti-inflammation, so we attempted to investigate the possible anticancer effect and mechanism of castanol B (1) against LPS-stimulated inflammatory hepatoma cells according to the link of inflammation to cancer.

LPS is a surface component of gramnegative bacteria and is known to be a strong stimulator of inflammatory response. Several studies verify that exposure of hepatoma cells to low concentration LPS enhances cell proliferation and survival, as well as induces progression of epithelial mesenchymal transition [14-16]. Because LPS induces both inflammatory response and proliferation on human hepatoma cells [17-19], it has been a representative cell model of inflammation-related hepatocellular carcinoma using LPS as stimulator. In this present study, we observed $50 \mathrm{ng} / \mathrm{mL}$ LPS induced proliferation of SMMC-7721 cells and HepG2 cells, while castanol B (1) inhibits the proliferation, which inhibitory effect might correlate its proapoptotic effect. Additionally, we found that castanol B (1) can promote the apoptosis of hepatoma cells in the absence of LPS.Because of its anti-inflammatory effect, it is proved that castanol B (1) inhibits the secretion of pro-inflammatory cytokines. Because castanol B (1) inhibits cytokines secretion and cell proliferation both in a dose-dependent 
manner, it speculates the correlation between anti-inflammation and anticancer by castanol B (1), and the anticancer mechanism might come from anti-inflammatory signal pathway.

LPS binds to Toll-like receptor 4 (TLR4) to activate cells in order to produce and release a large number of inflammatory cytokines, such as TNF- $\alpha$ and IL-6, then to trigger the inflammatory responses [20]. Activated TLR4 transduces the signal cascade to motive the transcriptional function of nuclear factor- $\mathrm{KB}(\mathrm{NF}-\mathrm{kB})$, which is considered as the main "switch" in secreting pro-inflammatory cytokines and regulating a variety of cytokines [21]. In physical status, NF- $\kappa$ Bbinds to its inhibitory protein, IKB, to form a complex, which is stabilized in the cytoplasm and cannot function as a transcription factor. In pathological status, IKB is phosphorylated by IKK kinase and releases NF- $\mathrm{B}$. Phosphorylated I $\mathrm{kB}$ is subsequently ubiquitinated and degraded by proteasome [22]. The dissociative NF- $\mathrm{KB}$ travels into cell nucleus, binds promoter sequences, and activates transcription of various genes leading to the transcriptional expression of downstream inflammatory molecules [23]. Thus, the TLR4-NF-KB pathway might be an important signal pathway, and might participate in LPS-induced cytokine increase and cell proliferation in hepatoma cells. In this study, castanol B (1) treatment decreases theprotein levels of three key signaling molecules in the LPS-induced TLR4-NF- $\mathrm{B}$ B pathway-TLR4, IKK $\beta$, and NF- $\mathrm{B}$ - - suggesting the anti-inflammtory mechanism of castanol B (1). Altogether, it is verified the anticancer effect of castanol B (1) is correlated with its anti-inflammtory mechanism.

Furthermore, because castanol B (1) works at a high concentration, such as $100 \mu \mathrm{M}$, and has the dual roles ofanticancer and anti-inflammation, its synergistic effect in combination with other agents or the ability to increase the sensitivity of other drugs should be explored.

\section{Materials and Methods}

\subsection{General}

Optical rotation was evaluated by a Bellingham and Stanley Ltd. 341 polarimeter (Bellingham and Stanley Ltd., Beaconsfield, UK). IR spectra wereobtained on a thermos Nicolet iS10 fourier transform infrared spectrometer with KBr pellets (Nicolet, Waltham, MA, USA). The UV spectrum was assessedusing a Mettle Toledo UV5 spectrometer (Mettle Toledo, Zurich, Switzerland). HRESIMS was measured with a Thermo Scientific ${ }^{\mathrm{TM}} 253$ Uitra Q-TOF MS (Thermo Scientific ${ }^{\mathrm{TM}}$, Waltham, MA, USA). NMR spectra wereperformed by a BRUKER AVANCE III-600 spectrometer (Bruker, Germany) using TMS as an internal standard. Preparative HPLC was run on Agilent Aupos Auto Purification System comprised ofan Agilent 2545 binary gradient module, a 2767 sample manager and a $2489 \mathrm{UV} /$ visible detector. Data was collected using a 1260 workstation (Agilent, Santa Clara, CA, USA). A preparative C18 column $(250 \times 20 \mathrm{~mm}$, i.d., $10 \mu \mathrm{m})$ was employed in HPLC separation.

\subsection{Plant Material}

The CMS was produced in Hubei Province, China, in July 2016, and accredited by Dr. Bao-Kang Huang (Second Military Medical University, China). A voucher specimen (Zheng 5590) has been archived in the Herbarium of the Shanghai University of Traditional Chinese Medicine.

\subsection{Water-Soluble Extract of CMS and Compound Isolation}

Dried and powdered CMS was extracted twice with 10 -fold weight of $40 \%$ ethanol for $2 \mathrm{~h}$, and the $\mathrm{pH}$ value was adjusted at $3-4$ using $\mathrm{HCl}$. The solution was filtrated and its residue was redissolved in water. The solution was evaporated to yield sample powder. Then the sample powder $(3 \mathrm{~kg})$ was extracted twice with methanol $(3 \times 10 \mathrm{~L})$ at room temperature for $15 \mathrm{~min}$ each. After filtration, the extracts were evaporated and dried using a rotary evaporator. Then $500 \mathrm{~mL}$ water was used for resolvation and was subsequently diluted 5 times. In order to eliminate baseline drift, the water solution was ultrafiltrated by a semipermeable membrane (5000 Da cutoff), then the filtrate was concentrated to $3.6 \mathrm{~L}$, and the crude extract was dried and weighed $68.04 \mathrm{~g}$. Finally, the crude extract 
was separated roughly into two parts by using self-made solid phase extraction column packed with $\mathrm{C}_{18} \mathrm{HC}$. The strong polar part and the weak polar part (21.54 g) were obtained by eluting with water $(280 \mathrm{~mL})$ and methanol $(280 \mathrm{~mL})$, respectively. The weak polar part was used for further chromatographic separation.

Preparative $\mathrm{C}_{18} \mathrm{ME} \mathrm{HPLC}\left(\mathrm{MeoH} / \mathrm{H}_{2} \mathrm{O}, 20 \%-72 \%, 40 \mathrm{~min}\right.$ ) was used to separate 12 fractions (Frs.1-12) from the weak polar part. Fr.2 was further separated by preparative $\mathrm{C}_{18} \mathrm{ME}$ column (ACN/ $\mathrm{H}_{2} \mathrm{O}, 5-15 \%, 20 \mathrm{~min}$ ) to afford two sub-fractions (Frs.2a-2b). Fr.2a was subjected to preparative C18 YE HPLC (ACN:H $\mathrm{H}_{2}$, 10:90) to afford compound 2 (32mg). Fr.2b was subjected to preparative $\mathrm{C}_{18} \mathrm{ME} \mathrm{HPLC}\left(\mathrm{ACN} / \mathrm{H}_{2} \mathrm{O}, 10-30 \%, 20 \mathrm{~min}\right.$ ) to give compounds 4 (28 mg). Fr.5 was separated by preparative $\mathrm{C}_{18} \mathrm{ME} \mathrm{HPLC}\left(\mathrm{ACN} / \mathrm{H}_{2} \mathrm{O}, 10-50 \%, 20 \mathrm{~min}\right)$ to afford compouds $6(10 \mathrm{mg})$ and 7 (9 mg). Fr.6 was further separated by semipreparative $\mathrm{C}_{18}$ ME HPLC (ACN:H $\left.{ }_{2} \mathrm{O}, 15: 85\right)$ to give compounds 1 (20 mg) and 5 (29 mg). Fr.8 was subjected to preparative C18 ME HPLC (ACN/ $\left.\mathrm{H}_{2} \mathrm{O}, 20-35 \%, 20 \mathrm{~min}\right)$ to yield compound 3 (23 $\mathrm{mg})$.

\subsection{Castanol B (1)}

Pale white and amorphous powder; $[\alpha]_{22}^{\mathrm{D}}+1000\left(c=0.001, \mathrm{M}_{\mathrm{e}} \mathrm{OH}\right) ; \mathrm{IR}(\mathrm{KBr}) v\left(\mathrm{~cm}^{-1}\right): 3289$, 1758, 1614, 1585, 1486; UV $\lambda \max (\mathrm{MeOH}) \mathrm{nm}(\log \delta): 210$ (3.52), 247 (4.09), 255 (3.12); HR-ESI-MS m/z 245.0462 (calculated 246.0533, for [M-H] $\left.{ }^{-}\right) ;{ }^{1} \mathrm{H}$ NMR (600 MHz, MeOD, oppm): $6.83(d, 1 \mathrm{H}, J=12.0 \mathrm{~Hz}$, $\left.5^{\prime}-\mathrm{H}\right), \delta_{\mathrm{H}} 6.95\left(d d, 1 \mathrm{H}, J=12.0,6.0 \mathrm{~Hz}, 6^{\prime}-\mathrm{H}\right), \delta_{\mathrm{H}} 7.05\left(d, 1 \mathrm{H}, J=6.0 \mathrm{~Hz}, 2^{\prime}-\mathrm{H}\right), \delta 7.15(s, 1 \mathrm{H}, 6-\mathrm{H}), 7.33(s$, 1H, 4-H), 7.66 (s, 1H, 2-H); ${ }^{13} \mathrm{C}$ NMR data: Table 1.

\subsection{7,8,dihydroxy-2H-chromen-3-one (2)}

Pale yellow and amorphous powder; $[\alpha]_{22}^{\mathrm{D}}+0.667\left(c=0.001, \mathrm{M}_{\mathrm{e}} \mathrm{OH}\right) ; \mathrm{IR}(\mathrm{KBr}) v\left(\mathrm{~cm}^{-1}\right): 3320$, 1762, 1615,1585, 1480; UV $\lambda \max (\mathrm{MeOH}) \mathrm{nm}(\log \delta): 227$ (3.41), 255 (4.32); HR-ESI-MS m/z 179.0467

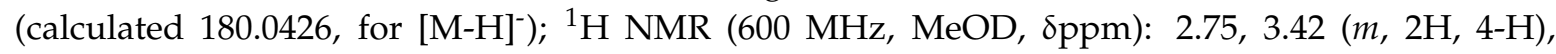
$4.40(m, 2 \mathrm{H}, 2-\mathrm{H}), 6.84(\mathrm{~s}, 1 \mathrm{H}, 6-\mathrm{H}), 7.07(\mathrm{~s}, 1 \mathrm{H}, 10-\mathrm{H}) ;{ }^{13} \mathrm{C}$ NMR data: Table 1.

\subsection{MTT Assay}

SMMC-7721 and HepG2 cells were purchased from Fuyang biotek company (Shanghai, China). The cells were trypsinized and seeded in 96-well plates at 2000/well. After overnight culture and removal of the medium cells were cultured in serum-free medium for another $24 \mathrm{~h}$. Then medium containing 1\% FBS, $50 \mathrm{ng} / \mathrm{mL}$ LPS (Sigma, MA, China) and various concentrations of compounds were used to treat the cells. After $48 \mathrm{~h}$ treatment, cell growth was determined by cell medium containing $0.5 \mathrm{mg} / \mathrm{mL}$ MTT in each well. After incubation for $2 \mathrm{~h}$, the optical density at $490 \mathrm{~nm}$ absorbance values was read.

\subsection{Cell Apoptosis Assay}

The hepatoma cells were trypsinized and seeded in 6-well plates at $1 \times 10^{5} /$ well, then, after overnight incubation, the medium was replaced and contained $50 \mathrm{ng} / \mathrm{mL}$ LPS and castanol B (1) (200 $\mu \mathrm{M}$ and $100 \mu \mathrm{M})$. After $48 \mathrm{~h}$ treatment, Annexin V-FITC/PI apoptosis kit (Beyotime, Shanghai, China) was used to determine the cell apoptosis according to the manufacturer's protocol. Briefly, cells were collected by trypsinization and washing, then resuspended in a buffer containing Annexin V-FITC and PI at manufacturer's specified concentrations for $15 \mathrm{~min}$ in the dark. Then the apoptotic cells were measured using a FACS Calibur flow cytometer (BD Biosciences, New York, NJ, USA).

\subsection{Cytokine Assays}

The concentrations of TNF- $\alpha$ and IL-6 (R\&D system, Saint Paul, MN, USA.) in supernatants were measured using ELISA kits. The minimum detectable concentrations of both kits were $2 \mathrm{pg} / \mathrm{mL}$. 


\subsection{Western Blotting}

After $48 \mathrm{~h}$ of LPS stimulation and $200 \mu \mathrm{M}$ castanol B (1) treatment, the hepatoma cells were lysed by lysis buffer and measured the total protein content by Coomassie brilliant blue assay. The proteins binding with SDS were electrophoresed on 10\% SDS-PAGE and transferred to PVDF membranes. Primary antibodies were used to immune-blot the membranes overnight at $4{ }^{\circ} \mathrm{C}$, followed by $2 \mathrm{~h}$ immune-blotting with secondary antibody (Boster, Wuhan, China) at room temperature. Then the bands were visualized using ECL method (Boster, Wuhan, China). Primary antibodies of TLR4, IKK $\beta$, and NF-кB p65 were purchased from Cell Signaling Technology (Saint Paul, MN, USA).

\section{Statistical Analysis}

We used the Student's $t$-tests to compare the differences between groups. SPSS program (v.13.0, SPSS, USA) was used to perform the statistical analysis. Results were presented as mean \pm SD with $p$-value less than 0.05 as statistical significance.

\section{Conclusions}

The present study demonstrates seven phenolic compounds structures separated from water-soluble extracts of shells of Castanea mollissima, in which castanol B (1) is a new phenol derivative which reduces inflammation, inhibits cell proliferation, and increases cell apoptosis of human hepatoma cells via inhibiting TLR4-NF- $\mathrm{B}$ pathway. This study enriches a new biphenyl derivative with physicochemical and biological activities. Furthermore, it provides new possibilities for the recycling of shells of Castanea mollissima (a waste from chestnut processing).

\section{Reference}

Author Contributions: L.Y., Y.Y.f., and Z.X. were responsible for the study concept, design, acquisition, and data analysis. W.F., Y.X., and X.J. conducted the chemical and biological experiments. W.Y. was responsible for purchasing. Y.Y.j., J.Y., and X.H. performed the cellular assays and data processing. L.Y., Y.Y.f., Z.X., and X.H. wrote the paper. L.Y., Y.Y.f., and Z.X. critically revised the article.

Funding: This research was funded by the Xinglin Young Scholar of Shanghai University of Traditional Chinese Medicine (grant number A1-U17205010416) and the Foundation of Shanghai Municipal Science and Technology Commission (grant number 16401901200).

Acknowledgments: This project was supported by Xinglin Young Scholar of Shanghai University of Traditional Chinese Medicine and the Shanghai Committee of Science and Technology, China (Grant No.16401901200).

Conflicts of Interest: The authors declare no conflicts of interest.

\section{References}

1. Jia, L.; Xi, F.; Wang, N.; Jing, L.L.; Kong, D.Y. Chemical Constituents of Castanea mollissima Blume Shell. Chin. J. Pharm. 2010, 41, 98-102.

2. FAOSTAT. Country Rank in the World, by Commodity: China. 1936-1944. Available online: http:/ / www. fao.org/faostat/en/\#rankings/countries_by_commodity (accessed on 23 October 2018).

3. You, T.T.; Zhou, S.K.; Wen, J.L.; Ma, C.; Xu, F. Chemical Composition, Properties, and Antimicrobial Activity of the Water-Soluble Pigments from Castanea mollissima Shells. J. Agric. Food. 2014, 62, 1936-1944. [CrossRef] [PubMed]

4. Zhang, H.; Ke, J.; Shao, T.; Li, J.; Duan, Y.; He, Y.; Zhang, C.; Chen, G.; Sun, G.; Sun, X. Cytotoxic effects of procyanidins from Castanea mollissimaBl. shell on human hepatoma G2 cells in vitro. Food. Chem. Toxicol. 2014, 64, 166-176. [CrossRef] [PubMed]

5. Hauer, H.; Germer, S.; Elsaber, J.; Ritter, T. Benzopyranones and Their Sulfate Esters from Pelargonium sidoides. Planta Med. 2010, 76, 350-352. [CrossRef] [PubMed]

6. Li, X.C.; Yang, L.X.; Wang, H.Q.; Chen, R.Y. Phenolic compounds from the aqueous extract of Acacia catechu. Chin. Chem. Letter. 2011, 22, 1331-1334. [CrossRef] 
7. Nawwar, M.A.M.; Hussein, S.A.M.; Merfort, I. NMR Spectral analysis of polyphenols from Puntica Granatum. Phytochemistry 1994, 36, 793-798. [CrossRef]

8. Sun, Y.N.; Li, W.; Song, S.B.; Yan, X.T.; Zhao, Y.; Reum Jo, A.; Jong, S.K.; Kim, Y.H. A new phenolic derivative with soluble epoxide hydrolase and nuclear factor-kappaB inhibitory activity from the aqueous extract of Acacia catechu. Nat. Prod. Res. 2016, 30, 2085-2092. [CrossRef]

9. Sun, H.; Liu, G.T. Chemopreventive effect of dimethyl dicarboxylate biphenyl on malignant transformation of WB-F344 rat liver epithelial cells. Acta Pharmacol. Sin. 2005, 26, 1339-1344. [CrossRef]

10. Jin, J.; Sun, H.; Wei, H.; Liu, G. The anti-hepatitis drug DDB chemosensitizes multidrug resistant cancer cells in vitro and in vivo by inhibiting P-gp and enhancing apoptosis. Investig. New Drugs 2007, 25, 95-105. [CrossRef]

11. Sun, H.; Liu, G.T. Inhibitory effect of dimethyl dicarboxylate biphenyl on invasionof humanhepatocellular carcinoma cell line MHCC97-H With high metastasis potential and its mechanisms. Chin. J. Cancer 2006, 25, 1464-1469.

12. Mantovani, A.; Allavena, P.; Sica, A.; Balkwill, F. Cancer-related inflammation. Nature 2008, 454, 436-444. [CrossRef] [PubMed]

13. He, G.; Karin, M. NF-кB and STAT3-key players in liver inflammation and cancer. Cell Res. 2011, 21, $159-168$. [CrossRef] [PubMed]

14. Wang, L.; Zhu, R.; Huang, Z.; Li, H.; Zhu, H. Lipopolysaccharide-induced toll-like receptor 4 signaling in cancer cells promotes cell survival and proliferation in hepatocellular carcinoma. Dig. Dis. Sci. 2013, 58, 2223-2236. [CrossRef]

15. Li, H.; Li, Y.; Liu, D.; Liu, J. LPS promotes epithelial-mesenchymal transition and activation of TLR4/JNK signaling. Tumour Biol. 2014, 35, 10429-10435. [CrossRef] [PubMed]

16. Jing, Y.Y.; Han, Z.P.; Sun, K.; Zhang, S.S.; Hou, J.; Liu, Y. Toll-like receptor 4 signaling promotes epithelial-mesenchymal transition in human hepatocellular carcinoma induced by lipopolysaccharide. BMC Med. 2012, 10, 98. [CrossRef] [PubMed]

17. Drucker, C.; Parzefall, W.; Teufelhofer, O.; Grusch, M.; Ellinger, A.; Schulte-Hermann, R.; Grasl-Kraupp, B. Non-parenchymal liver cells support the growth advantage in the first stages of hepatocarcinogenesis. Carcinogenesis 2006, 27, 152-161. [CrossRef]

18. Wang, Y.; Tu, Q.; Yan, W.; Xiao, D.; Zeng, Z.; Ouyang, Y.; Huang, L.; Cai, J.; Zeng, X.; Chen, Y.J.; et al. CXC195 suppresses proliferation and inflammatory response in LPS-induced human hepatocellular carcinoma cells via regulating TLR4-MyD88-TAK1-mediated NF-кB and MAPK pathway. Biochem. Biophys. Res. Commun. 2015, 456, 373-379. [CrossRef]

19. He, M.; Zhang, W.; Dong, Y.; Wang, L.; Fang, T.; Tang, W.; Lv, B.; Chen, G.; Yang, B.; Huang, P.; et al. Pro-inflammation NF-kB signaling triggers a positive feedback via enhancing cholesterol accumulation in liver cancer cells. J. Exp. Clin. Cancer Res. 2017, 36, 15. [CrossRef]

20. Quoilin, C.; Mouithys-Mickalad, A.; Duranteau, J.; Gallez, B.; Hoebeke, M. Endotoxin-induced basal respiration alterations of renal HK-2 cells: A sign of pathologic metabolism down-regulation. Biochem. Biophys. Res. Commun. 2012, 423, 350-354. [CrossRef]

21. Roman-Blas, J.A.; Jimenez, S.A. NF-kappaB as a potential therapeutic target in osteoarthritis and rheumatoid arthritis. Osteoarthritis Cartilage 2006, 14, 839-848. [CrossRef]

22. Blackwell, N.M.; Sembi, P.; Newson, J.S.; Lawrence, T.; Gilroy, D.W.; Kabouridis, P.S. Reduced infiltration and increased apoptosis of leukocytes at sites of inflammation by systemic administration of a membrane-permeable IkappaBalpha repressor. Arthritis Rheum 2004, 50, 2675-2684. [CrossRef] [PubMed]

23. Hayden, M.S.; Ghosh, S. Shared principles in NF-kappaB signaling. Cell 2008, 132, 344-362. [CrossRef] [PubMed]

(C) 2019 by the authors. Licensee MDPI, Basel, Switzerland. This article is an open access article distributed under the terms and conditions of the Creative Commons Attribution (CC BY) license (http:/ / creativecommons.org/licenses/by/4.0/). 